\title{
On the behaviour of pure cultures of marine micro-organisms in sterilized and re-inoculated sediments
}

\author{
W. E. Krumbein \\ Biologische Anstalt Helgoland (Meeresstation); Helgoland, Germany (FRG)
}

KURZFASSUNG: Uber das Verhalten von Reinkulturen mariner Bakterien in sterilisierten und wiederbesiedelten marinen Sedimenten. Im Anschluß an unsere Untersuchungen zur Bakterienverteilung in sterilisierten und durch Mischkulturen wieder beimpften Sedimenten wurden ähnliche Versuche mit Reinkulturen mariner Bakterien durchgeführt. Sedimentfraktionen definierter Korngröße wurden entsalzt, getrocknet und in Glaszylinder gefüllt. Diese wurden entweder mit oder ohne zusätzliche Nährböden im Autoklaven sterilisiert und anschließend mit Reinkulturen von Meeresbakterien, die aus Nordseesedimenten isoliert wurden, beimptt. Hierbei wurden jeweils wenige Zellen in den über dem Sediment stehenden Nährboden eingebracht. Das Verhalten der Bakterien wurde nach verschiedenen Zeitabständen durch Keimzahlbestimmungen im Überstand, an der Sedimentoberfläche und in $5 \mathrm{~cm}$ Tiefe überprüft. In Fällen, in denen mehrere Stämme gleichzeitig verwendet wurden, ließen sich diese durch die unterschiedliche Farbe der Kolonien auf Agar unterscheiden. Bei rascher Vermehrung im Überstand besiedelten die untersuchten Stämme sehr schnell die Sedimentoberfläche und drangen ebenso schnell bis zu $4 \mathrm{~mm}$ tief in das Sediment ein. In dieser obersten Sedimentzone übertrafen die Keimzahlen bereits nach 2 Tagen die Werte im Überstand. Einige der Stämme drangen sehr rasch, aber in geringeren Zahlen, auch bis zum Boden der Experimentiergefäße vor $(5 \mathrm{~cm}$ Tiefe). Bei der Verwendung verschiedener Sterilisierungsarten und verschiedener zusätzlicher Nährböden ergaben sich bei einem Stamm Verhaltensunterschiede. Es entwickelten sich andersfarbige Varianten. Die Zufügung von Sedimentextrakten zum klassischen Nährboden $2216 \mathrm{E}$ nach ZoBell erbrachte nach längerer Kultur in Sedimentsäulen die meisten Kolonien in der Originalfarbe. $\mathrm{Da}$ die Kulturgefäße während der Dauer des Versuches mechanisch nicht bewegt wurden, konnte eine schnelle aktive Durchwanderung des Sedimentes durch mobile Bakterien gezeigt werden. Dies wird durch die physikalischen Eigenschaften der Sedimente zum Teil behindert.

\section{INTRODUCTION}

It is well known that, under certain circumstances, marine micro-organisms grow better and develop higher numbers in environments with organic or inorganic particles. Jannasch (1954), Oppenheimer \& Jannasch (1962) and Zobell $(1937,1943)$ have found, that, in cases of low concentrations of organic matter, the adsorption of micro-organisms to particles is accentuated. Media without any particles develop lower numbers of micro-organisms, and the bacteria are commonly attached to the walls of the culture flask. The relation between bacteria and grain size distribution have been investigated by KRUMBEIN (1968). 
In marine microbiology the most important environments are those where two different media are in close connection e. g. the interface water/sediment or water/ atmosphere. The uppermost millimeters of a recent sediment is the zone of highest microbial activity (Hickel \& GUNKEL 1968, Hickel 1969). This is witnessed by high numbers of micro-organisms at the sediment surface and in the uppermost centimeters of a supernatant water column. During sedimentation it is possible that this zone is quickly buried under masses of rather sterile sand during tidal changes or after heavy storms. Therefore, it is a question of some interest, how bacteria behave in colums of sterile sediments. The seawater itself contains a lot of inorganic suspended matter with different numbers of bacteria attached to the particles (JANNASCH 1954, Armstrong 1958).

In addition to our investigation on the relations between bacteria and grain size distribution, we started a series of culture experiments with defined grain size fractions which were sterilized and inoculated with pure cultures of marine bacteria. Due to the quick changes in sedimentation, it may be assumed that sediments are often populated by organisms which live in the free water. Therefore, we inoculated the supernatant water column of our sediment filled glass cylinders. We wanted to get data on the settlement of bacteria in sterile sediments and on the time they needed to infiltrate actively into the sediment. Later on we tried to obtain information on the behaviour of different strains of marine bacteria when exposed to sterile sediments. Competition between two strains might give different types of populations within the sediment.

\section{METHODS}

\section{Sediments and preparation of sediment columns}

For all experiments we used sediment of the German Bight (southern North Sea) which was sampled in the silty region SW of Helgoland. We desalinized the sediments by wet sieving with fresh water and by washing the sieved fractions twice with distilled water. The sediments were then dried. The dry sediments were sieved again (dry sieving) to separate the different grain size fractions. The fractions were then mixed thoroughly in a mixing apparatus (FRITSCH PTL) to obtain homogenous material for experiments. By this treatment all soluble organic matter was removed. Only the original organic particles were not removed. For grain size analysis and determination of the most abundant fraction we followed the methods of KRUMBEIN \& Pettijohn (1938) and Mattiat (1964). We used two different fractionations for our cultural experiments. The fraction below $160 \mu$ and, for some experiments, the fraction below $400 \mu$. In both cases, the maximum of the sum curve was situated between 90 and $120 \mu$. The desalinized and sorted sediments were then filled to a height of $5 \mathrm{~cm}$ in glass cylinders of $10 \mathrm{~cm}$ diameter. Thus, we obtained a sediment column of homogenous structure and composition in every cylinder prepared. The sediment columns were then autoclaved, either without addition of media or after having filled the glass cylinders with liquid media. We autoclaved for 45 minutes at $120^{\circ} \mathrm{C}$. The cylinders, which were sterilized without medium, were filled after sterilization 
with media which had been sterilized in separate flasks. During the culture experiments, it was discovered that sterilization of sediments without added liquid, and sterilization of liquid saturated sediments, produces different results. All cylinders were filled in such a way as to obtain a saturated sediment column with $1 \mathrm{~mm}$ of supernatant liquid.

\section{Media}

Either before sterilization or, in other cases, after sterilization the sediment columns were saturated with one of the following media used during the experiments: (a) Medium $2216 \mathrm{E}$ after Zobell, modified by Gunkel (1964). The medium was used in its liquid phase during incubation and employed with 1.5\% Difco Bacto Agar for all plate counting tests during the incubation series.

(b) Medium $2216 \mathrm{E}$ with only $50 \%$ of organic compounds (peptone, yeast extract).

(c) Medium 2216 E: $750 \mathrm{ml}$ made up to $1,000 \mathrm{ml}$ with sediment extract.

(d) Sediment extract without additional nutrients. The sediment extract was prepared by adding $500 \mathrm{ml}$ of aged sea water to $1,000 \mathrm{ml}$ of a fresh wet sediment. The mixture was treated for $2 \mathrm{~h}$ in the open autoclave at $95^{\circ} \mathrm{C}$. The liquid was separated from the sediment by hot centrifugation because filtration was impossible, due to the clay mineral content of the sediment extracted; this does not influence the quality of the sediment extract (KRUMbein 1966).

(e) $750 \mathrm{ml}$ of aged sea water were made up to $1,000 \mathrm{ml}$ with distilled water. In this medium bacteria would grow only on the original organic matter of the prepared sediments:

(f) Medium to control the anaerobic growth of the selected strains of bacteria: Medium $2216 \mathrm{E}$ after Zobell with $5.0 \mathrm{~g}$ glucose and $0.1 \mathrm{~g}$ ascorbic acid added. This medium was used either liquid (in completely filled prescription bottles sealed with paraffin) or with $1.5 \%$ Difco Bacto Agar. The agar plates were then filled into metal cylinders, which were evacuated and filled with hydrogen.

\section{Strains of bacteria}

During the summers of 1968 and 1969, we isolated 80 strains of marine bacteria from sediments of the German Bight. These 80 strains were tested for their capability to grow under aerobic and anaerobic conditions. We separated the strains which were facultative aerobic and showed good growth under anaerobic conditions. From these strains we have chosen those which were motile by flagella and which had a characteristic colour which did not change after several passages on agar plates. In this way, 1 white, 2 red, 4 yellow, 3 orange and 2 blue strains were obtained.

A growth curve comparison of the strains mentioned gave us an impression of the multiplication rate of the different strains. The growth curves for marine bacteria in culture at $18^{\circ} \mathrm{C}$ have rather long logarithmic phases. The growth curves for 10 strains were produced by inoculating $50 \mathrm{ml}$ of $2216 \mathrm{E}$ medium with some cells of the strains. This culture was then aerated for $24 \mathrm{~h}$. From this culture $1 \mathrm{ml}$ was controlled 
microscopically. The culture was then diluted to obtain a certain cell concentration which was just below viability in liquid cultures; $1 \mathrm{ml}$ of the culture was then washed and inoculated to a fresh culture flask with $50 \mathrm{ml}$ of medium $2216 \mathrm{E}$. This flask was brought to a rotating culture device to obtain optimal aeration. A sample was taken every $4 \mathrm{~h}$ and the number of bacteria controlled by the plate counting method. For inoculation experiments we always used strains with nearly identical growth curves to reduce the influence of the different multiplication rates.

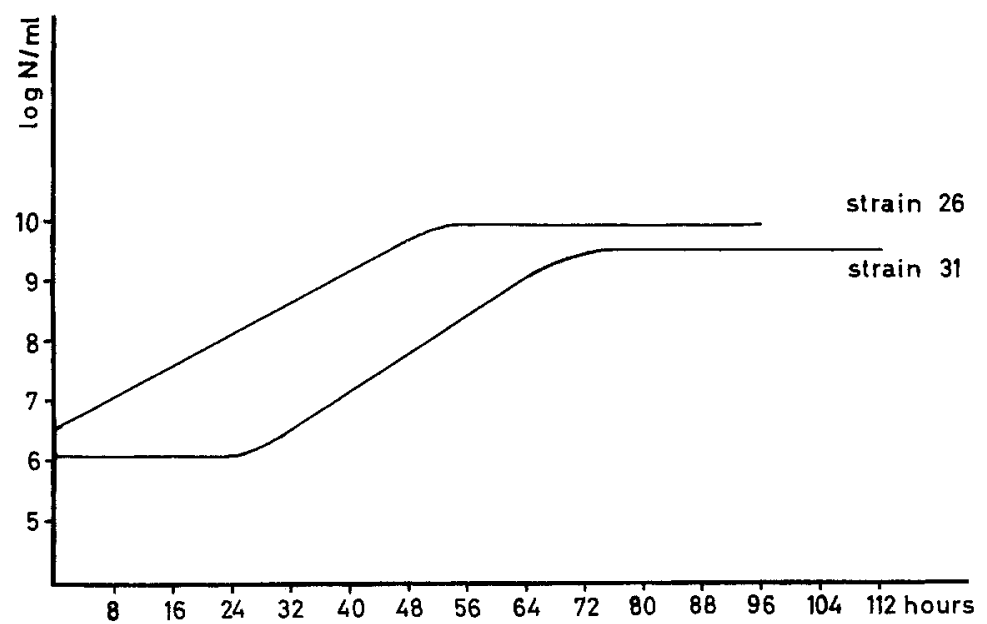

Fig. 1: Growth curve of bacteria strain 26 (yellow) and strain 31 (red). The end of the logarithmic phase of all tested strains varied between 42 and $124 \mathrm{~h}$

Most of the inoculation experiments were carried out with the following strains: Strain 26: heterotrophic, aerobic, growing well under anaerobic conditions (evacuated metal containers, hydrogen atmosphere); motile by flagella, rod shaped (about $1 \mu$ ); growing in distinct dark yellow colonies on $2216 \mathrm{E}$ agar. Strain 31: heterotrophic, aerobic, growing well under anaerobic conditions; motile by flagella, slightly smaller then strain 26, distinct red colonies on $2216 \mathrm{E}$ agar plates; only strains which did not change colour after several passages on $2216 \mathrm{E}$ agar plates were chosen.

\section{Proceeding}

The growth experiments were prepared in the following way: The glass cylinders with sterilized sediments and different liquid media were transported to the culture room $\left(18^{\circ} \mathrm{C}\right)$. In this room, without moving the cylinders, the supernatant liquid was inoculated. Usually 16 cylinders for each incubation series were prepared. We incubated with $1 \mathrm{ml}$ of a dilution with a defined cell number. The cells were taken from a culture at the beginning of the stationary phase and washed 3 times in a mixture of aged sea water and distilled water $(75+25 \mathrm{ml})$. Two control cylinders served as a blank. After 2, 4, 6, 9, 12, 15, and 23 days, two of the incubated glass 
cylinders were used for determination of cell numbers. To avoid any mechanical movement of the bacteria in the experimental assay, the sampling was done in the culture room.

We always took a sample of the supernatant liquid, a sample of the sediment surface and a sample from the bottom of the sediment column. The water sample was diluted and the cell number defined by the plate counting method using $2216 \mathrm{E}$ agar. The sediment sample was treated for 1 min with the ultra turrax mix (producer: JANKE \& KUNKEL) at $20000 \mathrm{rpm}$ to obtain an optimum suspension dilution series of the sediment. During treatment with the ultra turrax, the flask was cooled with ice to avoid heating by the mixing procedure (GUNKEL 1963). The suspension dilutions were then treated as the water sample. The counts from the supernatant liquid were expressed as $\mathrm{N} / \mathrm{ml}$, the counts from the sediment samples as $\mathrm{N} / \mathrm{g}$ dry weight. The humidity of the sediments, saturated with liquid medium, was always between 20.0 and $25.8 \%$.

\section{RESULTS}

From 7 series of inoculation experiments - of which 3 characteristic examples are documented in Tables 1-3 - we obtained some information on the active movement of bacteria into a sediment of known composition, and on the capacity of aerobic bacteria to develop under nearly anaerobic conditions. In series I and II the development of separate inoculates of strains 26 and 31 was tested. Series III (Table 1) shows the development of a mixed inoculation with strains 26 and 31 . In series IV we inoculated with a blue strain. This series was infected by a fungus which had possibly survived sterilisation. In series V (Table 2) the behaviour of strain 26 was tested by adding several different nutrient media to the sediment. In series VI the same was done for strain 31 (Table 3). Series VII, which was inoculated 2 weeks after series VI was scheduled to reveal the behaviour of strains 26 and 31 in different media. However, strain 31 changed colour as in series VI, and we had no possibility to separate the 2 strains on the plates.

Strains 26 and 31 usually developed very quickly after incubation in the supernatant liquid. In some cases, even after 2 days, strain 26 reached the sediment surface and exceeded the numbers of bacteria in the supernatant liquid. Strain 26 reached the bottom of the sediment in all experiments and with all media added. The counts usually remained between 4 and 7 exponents lower then that at the sediment surface. Strain 31 developed in about the same way, both at the sediment surface and at the bottom, in case of wet sterilisation of the sediment (i. e. sterilisation of sediment and medium together). However, strain 31 did not reach the bottom of the sediment, except in the cylinders of the 4th day (Table 1) and in the cylinders with additional sediment extract (Table 3 ) in case of dry sterilisation of the sediment.

To control the influence of dry sterilisation on the sediments we tested several media added to dry sterilized sediment columns. In experiment V (Table 2) the sediments were incubated with additional sea water only, with sediment extract, with a mixture of sediment extract and medium $2216 \mathrm{E}$, or with pure medium $2216 \mathrm{E}$. The yellow strain did not change its behaviour. In fact, it developed as fast in pure 
W. E. KRUMBEIN

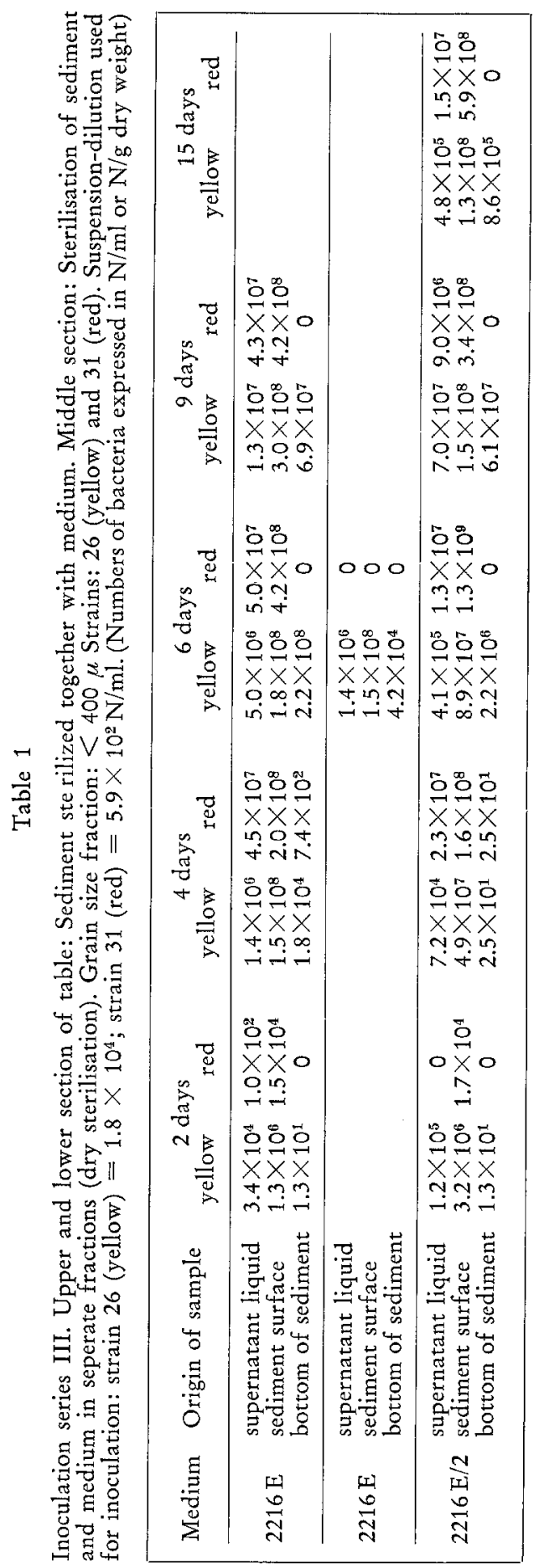




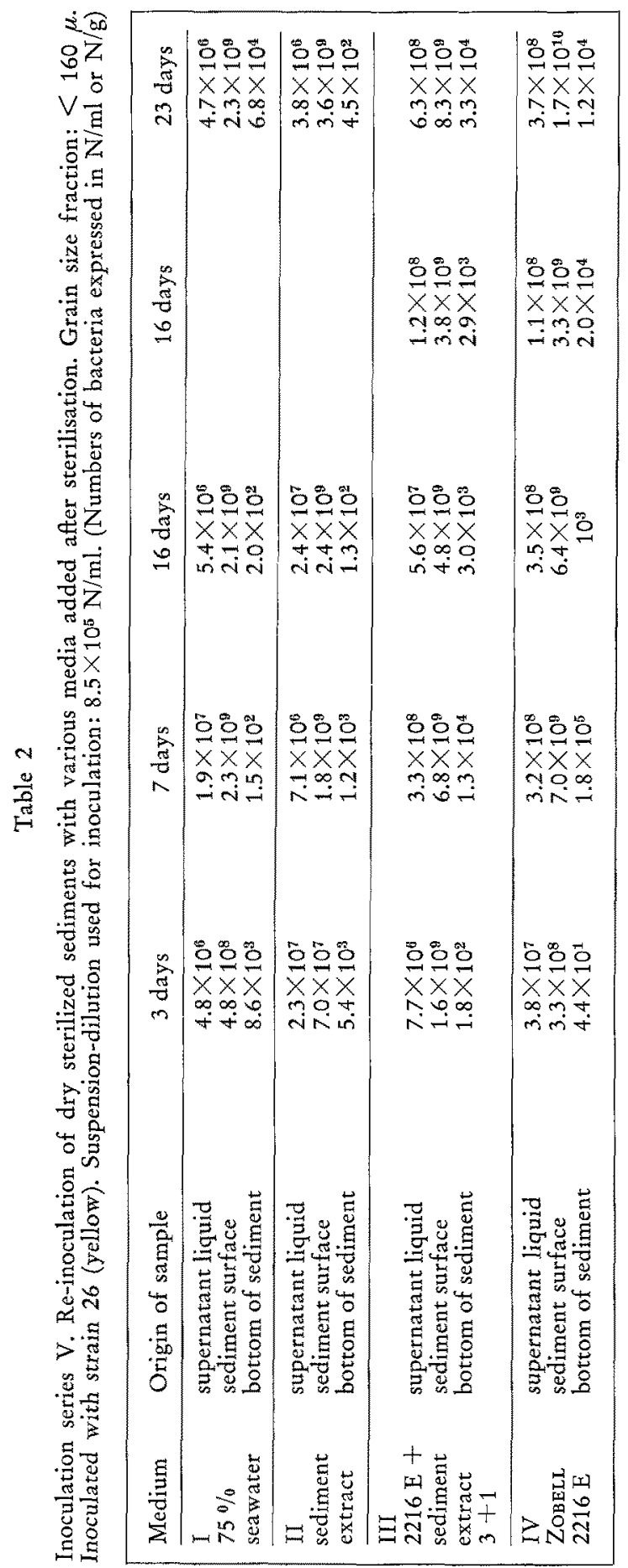


Table 3

Inoculation series VI. Re-inoculation of dry sterilized sediments (fraction below $160 \mu$ ) with various media added after sterilisation. Bacteria strain 31 (red). Suspension-dilution used for inoculation: $3.4 \times 10^{4} \mathrm{~N} / \mathrm{ml}$. (Numbers of bacteria expressed in $\mathrm{N} / \mathrm{ml}$ or N/g dry weight)

\begin{tabular}{|c|c|c|c|c|c|}
\hline Medium & Origin of sample & $\begin{array}{l}\text { Colour a } \\
\text { grey-white }\end{array}$ & $\begin{array}{c}\text { nd number of } \mathrm{c} \\
\text { solid } 2216 \mathrm{E} \\
\text { pale-yellow }\end{array}$ & $\begin{array}{l}\text { olonies on } \\
\text { orange-red }\end{array}$ & $\begin{array}{l}\text { Incubation } \\
\text { time (days) }\end{array}$ \\
\hline $\begin{array}{l}75 \% \\
\text { sea } \\
\text { water }\end{array}$ & $\begin{array}{l}\text { supernatant liquid } \\
\text { sediment surface } \\
\text { bottom of sediment }\end{array}$ & $\begin{array}{l}0 \\
0 \\
0\end{array}$ & $\begin{array}{l}3.5 \times 10^{7} \\
4.8 \times 10^{8} \\
2.2 \times 10^{2}\end{array}$ & $\begin{array}{l}0 \\
0 \\
0\end{array}$ & 3 \\
\hline $\begin{array}{l}\text { sediment } \\
\text { extract }\end{array}$ & $\begin{array}{l}\text { supernatant liquid } \\
\text { sediment surface } \\
\text { bottom of sediment }\end{array}$ & $\begin{array}{l}0 \\
0 \\
0\end{array}$ & $\begin{array}{l}4.6 \times 10^{7} \\
5.0 \times 10^{8} \\
1.6 \times 10^{6}\end{array}$ & $\begin{array}{c}2.3 \times 10^{2} \\
3.5 \times 10^{4} \\
0\end{array}$ & 3 \\
\hline $\begin{array}{l}\text { sediment } \\
\text { extract }+ \\
2216 \text { E } 1: 3\end{array}$ & $\begin{array}{l}\text { supernatant liquid } \\
\text { sediment surface } \\
\text { bottom of sediment }\end{array}$ & $\begin{array}{l}0 \\
0 \\
0\end{array}$ & $\begin{array}{l}6.7 \times 10^{8} \\
4.0 \times 10^{8} \\
1.3 \times 10^{4}\end{array}$ & $\begin{array}{c}0 \\
1.6 \times 10^{3} \\
0\end{array}$ & 3 \\
\hline $\begin{array}{l}\text { medium } \\
2216 \mathrm{E}\end{array}$ & $\begin{array}{l}\text { supernatant liquid } \\
\text { sediment surface } \\
\text { bottom of sediment }\end{array}$ & $\begin{array}{l}5.0 \times 10^{4} \\
7.0 \times 10^{6} \\
9.0 \times 10^{1}\end{array}$ & $4.0 \times 10^{5}$ & $\begin{array}{l}0 \\
0 \\
0\end{array}$ & 3 \\
\hline $\begin{array}{l}75 \% \\
\text { sea } \\
\text { water }\end{array}$ & $\begin{array}{l}\text { supernatant liquid } \\
\text { sediment surface } \\
\text { bottom of sediment }\end{array}$ & $\begin{array}{l}0 \\
0 \\
0\end{array}$ & $\begin{array}{c}1.0 \times 10^{3} \\
2.4 \times 10^{6} \\
0\end{array}$ & $\begin{array}{l}0 \\
0 \\
0\end{array}$ & 7 \\
\hline $\begin{array}{l}\text { sediment } \\
\text { extract }\end{array}$ & $\begin{array}{l}\text { supernatant liquid } \\
\text { sediment surface } \\
\text { bottom of sediment }\end{array}$ & $\begin{array}{c}0 \\
5.7 \times 10^{4} \\
0\end{array}$ & $\begin{array}{l}3.0 \times 10^{7} \\
2.9 \times 10^{8} \\
3.6 \times 10^{3}\end{array}$ & $\begin{array}{l}3.0 \times 10^{3} \\
1.2 \times 10^{8} \\
7.0 \times 10^{1}\end{array}$ & 7 \\
\hline $\begin{array}{l}\text { sediment } \\
\text { extract }+ \\
2216 \mathrm{E} 1: 3\end{array}$ & $\begin{array}{l}\text { supernatant liquid } \\
\text { sediment surface } \\
\text { bottom of sediment }\end{array}$ & $\begin{array}{l}0 \\
0 \\
0\end{array}$ & $\begin{array}{l}4.6 \times 10^{5} \\
2.2 \times 10^{6} \\
1.8 \times 10^{2}\end{array}$ & $\begin{array}{c}9.0 \times 10^{2} \\
8.0 \times 10^{1} \\
0\end{array}$ & 7 \\
\hline $\begin{array}{l}\text { medium } \\
2216 \mathrm{E}\end{array}$ & $\begin{array}{l}\text { supernatant liquid } \\
\text { sediment surface } \\
\text { bottom of sediment }\end{array}$ & $\begin{array}{c}9.0 \times 10^{5} \\
4.0 \times 10^{7} \\
0\end{array}$ & $\begin{array}{l}2.0 \times 10^{5} \\
8.0 \times 10^{6} \\
10^{2}\end{array}$ & $\begin{array}{l}0 \\
0 \\
0\end{array}$ & 7 \\
\hline $\begin{array}{l}75 \% \\
\text { sea } \\
\text { water }\end{array}$ & $\begin{array}{l}\text { supernatant liquid } \\
\text { sediment surface } \\
\text { bottom of sediment }\end{array}$ & $\begin{array}{l}1.7 \times 10^{3} \\
3.4 \times 10^{5} \\
2.1 \times 10^{2}\end{array}$ & $\begin{array}{l}4.6 \times 10^{5} \\
6.5 \times 10^{7} \\
1.3 \times 10^{2}\end{array}$ & $\frac{0}{1.5 \times 10^{3}}$ & 23 \\
\hline $\begin{array}{l}\text { sediment } \\
\text { extract }\end{array}$ & $\begin{array}{l}\text { supernatant liquid } \\
\text { sediment surface } \\
\text { bottom of sediment }\end{array}$ & $\begin{array}{l}5.1 \times 10^{6} \\
2.8 \times 10^{8} \\
2.2 \times 10^{2}\end{array}$ & $\begin{array}{l}\text { contaminated } \\
\text { by fungi }\end{array}$ & $\begin{array}{l}7.0 \times 10^{4} \\
3.0 \times 10^{8} \\
2.2 \times 10^{2}\end{array}$ & 23 \\
\hline $\begin{array}{l}\text { sediment } \\
\text { extract }+ \\
2216 \text { E } 1: 3\end{array}$ & $\begin{array}{l}\text { supernatant liquid } \\
\text { sediment surface } \\
\text { bottom of sediment }\end{array}$ & $\begin{array}{l}4.2 \times 10^{6} \\
4.0 \times 10^{9} \\
6.0 \times 10^{5}\end{array}$ & $\begin{array}{l}2.8 \times 10^{6} \\
4.5 \times 10^{8} \\
1.8 \times 10^{4}\end{array}$ & $\begin{array}{l}8.5 \times 10^{6} \\
2.0 \times 10^{7} \\
7.8 \times 10^{3}\end{array}$ & 23 \\
\hline $\begin{array}{l}\text { medium } \\
2216 \mathrm{E}\end{array}$ & $\begin{array}{l}\text { supernatant liquid } \\
\text { sediment surface } \\
\text { bottom of sediment }\end{array}$ & $\begin{array}{l}8.0 \times 10^{6} \\
3.4 \times 10^{8} \\
5.6 \times 10^{5}\end{array}$ & $\begin{array}{l}6.7 \times 10^{8} \\
3.4 \times 10^{9} \\
5.3 \times 10^{2}\end{array}$ & $6.2 \times 10^{2}$ & 23 \\
\hline
\end{tabular}

sea water as in the medium $2216 \mathrm{E}$ after ZoBELL. The original organic content of the sediments was sufficient to support growth of this strain without additional nutrients. The final number of bacteria was only slightly higher with medium 2216 E. Counts 
at the bottom of the sediment stayed at a lower level than on wet sterilisation. The addition of sediment extract to the media did not significantly change the culture environment for strain 26.

Strain 31 developed in an irregular manner on sediment columns which had been sterilized before addition of nutrient media. The dry sterilized sediments produced large differences in the cultural behaviour of strain 31 on agar-plates. The strain grew in large numbers on all media, but changed colour and did not reach the bottom of the sediment in some cases. Whereas before inoculation, this strain always grew in distinct red colonies on agar plates with medium $2216 \mathrm{E}$, it changed colour after inoculation. We had to separate at least 3 types of colonies which are listed in Table 3. The colour of the colonies varied between white-grey, pale yellow and orange-dark red. From this we concluded that strain 31 was influenced by the method of sterilisation of the sediment as well as by the inoculation in different media. It seems that the physical conditions in the sediment are changed by sterilisation as well as the composition of organic matter in the original sediment. Strain 31, which always showed red colonies on $2216 \mathrm{E}$ agar plates, produced red colonies only after inoculation on dry sterilized sediments when inoculation was done in media containing sediment extract. Also, its capability to reach the bottom of the sediment columns was influenced by the method of sterilisation and by the type of nutrient medium.

\section{DISCUSSION}

The different results obtained with the 2 strains are not easy to interpret. We can conclude from the culture experiments that the opinion of various authors, who investigated the influence of particles on the growth of bacteria, also holds true for sediment particles. The presence of particles gives significantly higher numbers of bacteria per unit volume than particle free solutions. Bacterial counts at the sediment/ water interface are much higher, even when the nutrient concentration in the liquid and solid phase is the same. With increasing depth, the number of bacteria decreases. This does not depend on nutrient concentration. Decreasing oxygen content influences the various species in different ways, but the numbers of all bacteria (aerobic as well as anaerobic) decrease with increasing depth.

WAGNER \& SCHWARTZ (1963) have shown the migration of bacteria through recent sediments. STEIGER (1957) has studied the migration of bacteria through soils. Our experiments have proved that bacteria are capable of active movement through recent sediments, and that this movement is rather fast even under stagnating conditions.

These facts might throw some light on the observations of OPPENHEIMER (1960) who related the different numbers of bacteria in various layers of sediments to migration rates through the sediment. A large number of the isolated strains we tested for our experiments were able to grow under aerobic and under anaerobic conditions. The fact that usually aerobic bacteria can move actively to nearly anerobic regions of the sediment, may give some explanation for the reported counts 
of HiCKEL (1969) and others (ZOBELl 1936). All authors who provide data on bacteria distributions in sediments, mention the fact that, with increasing depth the number of anaerobic bacteria does not increase compared with aerobic bacteria, while the total number of bacteria usually decreases.

The change of colour of strain 31, after inoculation to sterilized sediments, may be connected with surface tension and surface active substances as discussed by JANNASCH (1959) and MAC LEOD et al. (1958). It is known that surface active substances may influence the growth of bacteria. Additionally, clay minerals, which have very typical surfaces with various differences in surface tension, and peptisation effects may influence the growth of bacteria (STOTZKy 1967). JANNASch (1959) demonstrated that, in cases of culture in liqued media, the influence of surface active substances was more important than that on agar media. Thus, it may be that the subculture in sterile sediments may have influenced strain 31 to produce variants or, at least, modifications of different colours. Some of the yellow colonies remained yellow after several new passages on $2216 \mathrm{E}$ agar plates, whereas other colonies returned to red after subculturing them on agar plates. The added sediment extract seems to have produced a positive effect on the sediments, because inoculates in media with sediment extract gave higher numbers of bacteria with the original red colour.

The investigation of cultural behaviour of bacteria in the sedimentary environment is very difficult, due to the complexity of the medium. We hope to obtain more results with pure quarz sands or other artificial sediments as well as with natural sediments treated with $\mathrm{H}_{2} \mathrm{O}_{2}$ and other substances to eliminate the original organic content.

\section{SUMMARY}

1. The behaviour of pure cultures of marine micro-organisms in sterilized sediments was studied by inoculation of the supernatant liquid media with mobile bacteria.

2. The largest numbers of bacteria developed at the sediment surface down to $4 \mathrm{~mm}$ depth and not in the supernatant liquid, in spite of the fact that the supernatant liquid only was inoculated.

3. Most of the strains tested reached the bottom of the sediment within a few days.

4. Strain 31 did not reach the bottom of the sediment in case of dry sterilisation of the sediment column.

5. Strain 31 developed in all media different coloured variants, except in media with additional sediment extract where the original red colour remained. In these media bacteria reached well to the bottom of the sediment columns tested.

6. The original organic matter of the sediment fractions tested was usually sufficient to support growth of the bacteria examined. After several days of incubation, bacteria reached the same numbers as was the case with additional nutrient substances.

7. Active movement of bacteria through fine grained sediments is possible. Population of sterile sediments from the supernatant water column is possible and progresses rapidly. 
8. Decrease in bacteria numbers with increasing sediment depth is not connected to nutrient concentration.

\section{LITERATURE CITED}

Armstrong, F. A. J., 1958. Inorganic suspended matter in sea water. J. mar. Res. 17, 23-34. Gunkel, W., 1964. Die Verwendung des Ultra-Turrax zur Aufteilung von Bakterienaggregaten in marinen Proben. Helgoländer wiss. Meeresunters. 11, 287-295.

- \& OpPenhermer, C. H., 1963. Experiments regarding the sulfide formation in sediments of the Texas gulf coast. In: Symposium on marine microbiology. Ed. by C. H. Oppenheimer. C. C. Thomas, Springfield, Ill., 674-684.

- \& Rheinheimer, G., 1968. Bakterien. In: Methoden der meeresbiologischen Forschung. Hrsg. von C. Schlieper. Fischer, Jena, 142-157.

HICKEL, W., 1969. Sedimentbeschaffenheit und Bakteriengehalt im Sediment eines zukünftigen Verklappungsgebietes von Industrieabwässern nordwestlich Helgolands. Helgoländer wiss. Meeresunters. 19, 1-20.

- \& Gunkel, W., 1968. Untersuchungen über die Häufigkeit der Bakterien in der obersten Sedimentschicht der Deutschen Bucht in Beziehung zu den Substrateigenschaften. Helgoländer wiss. Meeresunters. 18, 213-231.

JaNNASCH, H. W., 1954. Okologische Untersuchungen der planktischen Bakterienflora im Golf von Neapel. Naturwissenschaften 41, 42-43.

JoNES, G. E. \& JANNASCH, H. W., 1959. Aggregates of bacteria in sea-water as determined by treatment with surface-active substances. Limnol. Oceanogr. 4, 269-276.

Krumbein, W. C. \& Pettijohn, F. H., 1938. Manual of sedimentary petrography. AppletonCentury, New York, 549 pp.

Krumbern, W. E., 1966. Zum Problem der Bestimmung der Gesamtmikroflora mittels eines Bodenextraktes. Biol. Sol 5, 18-19.

- 1970. Sedimentmikrobiologische Untersuchungen. Uber die Abhängigkeit der Keimzahl von der Korngröße. In: Comptes rendus du 3e Symposion européen de biologie marine. (In press.)

Macleod, R. A., Hogenkamp, H. \& ONofRey, E., 1958. Nutrition and metabolism of marine bacteria. VII. Growth response of marine flavo-bacterium to surface-active agents and nucleotides. J. Bact. 75, 460-466.

Matтiat, B., 1964. Methodische Verbesserungen bei der routinemäßigen Schlämmanalyse von Ton- und Bodenproben. Beitr. Miner. Petrogr. 10, 216-224.

Oppenheimer, C. H., 1960. Bacterial activity in sediments of shallow marine bays. Geocbim. cosmochim. Acta 19, 244-260.

- \& Jannasch, H. W., 1962. Some bacterial populations in turbid and clear water near Port Aransas, Texas. Publs Inst. mar. Sci. 8, 56-60.

SIEBert, G. \& SchWartz, W., 1956. Untersuchungen über das Vorkommen von Mikroorganismen in entstehenden Sedimenten. Arch. Hydrobiol. 52, 321-366.

STEIGER, W., 1957. Filtrationsversuche mit Aufschlämmungen von Coli- und Typhusbakterien an natürlich gelagerten Bodenschichten. Nat.-math. Diss., Frankfurt a. M.

Stotzky, G., 1967a. Influence of clay minerals on microorganisms. 4. Can. J. Microbiol. 13, $1535-1550$.

- 1967b. Influence of cations on the floculation of clay minerals by microbial metabolites as determined by the electrical sensing zone particle analyzer. Proc. Soil. Sci. Soc. Am. 31, 761-765.

WAGNER, M. \& SCHWARTZ, W., 1963. Behaviour of a suspension of microbes migrating through sediments under marine and limnic conditions. In: Symposium on marine microbiology. Ed. by C. H. Oppenheimer. C. C. Thomas, Springfield, Ill., 179-187.

WeIleR, R. R. \& Mills, A. A., 1965. Surface properties and pore structure of marine sediments. Deep-Sea Res. 12, 511-529. 
ZoBelL, C. E., 1937. The influences of solid surfaces on the physiological activities of bacteria in sea water. J. Bact. 33, 86.

- 1943. The effect of solid surfaces upon bacterial activity. J. Bact. 46, 39-56.

- \& Anderson, D. Q., 1936. Vertical distribution of bacteria in marine sediments. Bull. Am. Petrol. Geol. 20, 258-269.

Author's address: Dr. W. Krumbeln

Biologische Anstalt Helgoland

Meeresstation

2192 Helgoland

Germany (FRG) 